\title{
Identifying risks for mental health problems in HIV positive adolescents accessing HIV treatment in Johannesburg
}

\section{Introduction}

Mental health needs of children and adolescents globally do not get the attention and resources required, but are severely underserved in low and middle-income countries (LMICs) (Cortina et al, 2012; Becker \& Kleinman, 2013; Gore et al, 2011; Patel et al, 2007; Kieling et al, 2011). Mental disorders account for a large proportion of disease burden and mortality in young people in all societies, but especially so for youth in LMICs as a result of scarce resources and strong associations with social determinants of health, such as poverty, food insecurity, violence, poor access to education and healthcare etc. (Patel et al, 2007). The HIV pandemic has increasingly brought attention to the unmet mental health needs of children and adolescents (Breuer et al, 2011), highlighting the necessity to integrate HIV and mental health care as positive mental health is critical in the management of HIV disease (Mellins \& Malee, 2013; Lowenthal et al, 2014; Sherr et al, 2014; Stein et al, 2014).

Children and adolescents make up a significant proportion of the population in LMICs; many of whom are HIV infected. Approximately 2.1 million adolescents in LMICs were living with HIV in 2012, and of the estimated 3.2 million children under the age of 15 years infected with HIV globally, $90 \%$ are living in sub-Saharan Africa (WHO, 2013; UNAIDS, 2014). In 2012 it was estimated that there were approximately 369,000 adolescents under the age of 14 years and 720,000 15 to 24 year olds living with HIV in South Africa (Simbayi et al, 2014). In addition, nearly one-sixth of all new HIV infections are among adolescents 15 to 19 years (UNICEF, 2013). As antiretroviral therapy (ART) continues to be scaled up in LMICs and improve morbidity and mortality outcomes associated with HIV infection, prevention of new HIV infections among adolescents is critical (Davies \& Pinto, 2015). Increased efforts are required to understand the global health needs of this population (including mental health needs) to mitigate and prevent secondary transmission, and manage consequent adult burden of disease as they transition from adolescence.

Research indicates that perinatally infected HIV positive adolescents tend to have high levels of common mental health problems (Lowenthal, 2014; Mellins \& Malee, 2013) and that this has direct negative effects on adherence to ART (Kim et al 2014; Hudelson \& Cluver, 2015; Nel \& Kagee, 2011), retention in care (Lowenthal, 2014; Agwu \& Fairlie, 2013), and high risk sexual behaviors (Mellins et al, 2011; Gadow et al, 2012). These factors lead to risk for secondary transmission. Evidence suggests that mental health in this population is significantly related to exposure to violence (Skeen et al, 2016); levels of connectedness, future orientation and hope (Petersen et 
al, 2010; Bernays et al, 2007); and disclosure (Lowenthal et al, 2014). There have been consistent calls to improve prevention and research efforts regarding adolescent mental health and HIV (Ordonez \& Collins, 2015; Mofenson \& Cotton, 2013) in attempts to further policy recommendations and strengthen the evidence base of mental health needs of youth in South Africa. Little is known of the mental health of perinatally infected HIV positive adolescents accessing care and treatment within the healthcare system. This study investigated the common mental health problems evident (depression, anxiety, post traumatic stress disorder (PTSD), suidicality) in perinatally infected adolescents retained in care in Johannesburg. Risk and protective factors related to mental health in this population were examined.

\section{Methods}

\section{Participants and procedures}

We assessed the mental health of $n=343$ HIV positive adolescents accessing five pediatric ARV clinics serving adolescents in Johannesburg. Three clinics were hospital based; one was a community health center and one a primary healthcare clinic. All were located in urban settings characterized by poverty, violence and poor infrastructure. Data was collected over a period of 8 months. Participants were aged between 13 and 19 years, the majority were on treatment for HIV (92\%) and most had been attending the clinics since early childhood. Although it was challenging to distinguish source of HIV infection, most had lived with HIV for as long as they remembered and hence were categorized as perinatally infected. It is possible that a proportion was infected through blood transfusion or rape in childhood and 4 participants were known to be horizontally infected (1\%). Study participants consented to participate in a 90 minute structured questionnaire administered on tablet computers. Research counsellors facilitated the questionnaires, were known to the adolescents and routinely provided direct services to them as clinic counselors. Trained in pediatric HIV and advanced counselling, these counsellors were willing to participate in the research, engaging in principles of ethical research with minors (Clacherty \& Donald, 2007). They received an additional 5 day training for this study, with an emphasis on distress protocol management and had weekly supervisory debriefing from a registered therapist throughout the course of data collection.

All data collected were identified by a unique participant number and kept in confidential files and tablet computers with no identifying information.

Confidentiality was maintained unless participants reported abuse or were at risk of significant harm. Where prior abuse or rape had occurred $(n=4)$, referrals were made to support and counselling services. Where there was active suicidality $(n=17)$, participants were screened out of the study with active referrals made for immediate 
care.

Participants were given a pocket sized card with referrals for services in their neighbourhood including counselling, legal and crisis resources. Upon completion of the interview, participants received reimbursement for travel; a snack; and a gift voucher for R50 (\$4) at a clothing retailer. These items were endorsed and recommended by the adolescent community advisory board (CAB) instituted for this research.

\section{Ethical consideration}

The South African National Health Act states that 'for health research with minors (<18 year olds), consent from a legal parent or guardian for research with children must be obtained' (Section 71, 2012). This sample was speculated to not have "legal" guardians from whom to obtain consent, it being well known that perinatally infected adolescents are frequently orphaned and in the care of extended family members who are seldom legal guardians. As such, the medical research ethics committee of the University of the Witwatersrand advised obtaining a court order which was granted and led to full ethics clearance and permission to interview volunteers without parental or guardian consent (M130258). Permission was also granted from Gauteng Provincial Department of Health, Johannesburg District Department of Health, and the research committees of facilities. Adolescents gave verbal assent and written consent to participate in the research, and all participation was sought on the basis of good clinical practice guidelines (Verma, 2013).

\section{Measures}

\section{Sociodemographic information}

Items were derived from the South African census and included age, gender, ethnicity, household composition, formal/informal housing, highest school grade achieved, and orphanhood status. Household level questions used previously in research with orphaned children in South Africa (Cluver et al, 2012) were included to determine caretaking responsibilities as well as sense of belonging.

\section{Mental health measures}

Mental health was measured using standardized scales utilized previously with youth in South Africa (Cluver et al, 2012). Depression was measured with the 10-item Child Depression Inventory Short Form (Kovacs, 1992), highly correlated with the full scale ( $r$ 0.89; Kovacs, 1992); $\alpha=.70$. Anxiety was measured using an abbreviated version of the 28-item Revised Children's Manifest Anxiety Scale (Reynolds \& Paget, 1983), 
which has been validated for use in South Africa (Boyes \& Cluver, 2012); $\alpha=.75$. Posttraumatic stress symptoms were measured using the Child PTSD Checklist (Amaya-Jackson, 1995) and has been validated in South Africa (Boyes et al, 2012); $\alpha=.89$. Suicidal behavior was measured with the MINI International Psychiatric Interview for children and adolescents suicide scale (Sheehan et al, 2004). This scale is well validated, showing strong internal consistency and test-retest reliability (Lecrubier et al, 1997); $\alpha=.75$.

Western-validated clinical scores must be interpreted with caution, and to date no clinical cut-offs have been validated in Africa. Resultantly a symptomatic group was identified as adolescents who experienced $>50 \%$ of the symptoms on any of the depression, anxiety or PTSD scales.

Hypothesized risk variables are summarized in table 1

(insert table 1 here)

\section{Analysis strategy}

Data were analysed using Statistica v13. Descriptive and bivariate analyses were conducted to examine the distribution of all variables at each time point and assess relationships between variables. Descriptive analyses were run on all variables. Normality was assessed using Kolmogorov-Smirnov and the Shapiro-Wild tests and histograms generated for graphical confirmation. Pearson's $r$ was used to measure the correlation between variables and T-tests used to compare differences between groups. Chi-squared tests were used to determine statistically significant differences in responses to categorical variables. Relative risks and $95 \%$ confidence intervals $(\mathrm{Cl})$ were calculated using Altman's formula (Altman, 1991).

\section{Results}

The mean age of participants was 16 years, $52 \%$ were female. The sample showed moderate financial means: $76 \%$ were living in brick houses, $95 \%$ had electricity and $92 \%$ were in possession of cellphones. The vast majority was orphaned (73\%; 32\% double orphans) and living either with extended family members (285 participants, $83 \%$ ) or in children's homes (5 participants, 1.5\%). Participants demonstrated high caretaking responsibilities with $37 \%$ reporting looking after younger children in the home and $53 \%$ looking after someone sick in the home. $89 \%$ of participants reported they did not feel they belonged in the family they were being raised in, $90 \%$ reported that they did not get praise from those they live with, and $85 \%$ reported they did not get the same things as other children in the home. Only $18 \%$ of the sample had not experienced a major loss (parent, sibling, primary caregiver) to date. A third of 
participants had experienced more than one major loss of a family member. Interestingly, from a patient population well versed in accessing services through most of their childhood, only $89 \%$ knew why they were coming to the clinic and $6 \%$ reported they did not know their HIV status. Of those who reportedly knew their status (89\%), mean age of disclosure was 12 years. In addition, although they had been disclosed to, only $51 \%$ reportedly knew how they contracted HIV.

Around one third (27\%) of the sample was symptomatic for depression, anxiety or PTSD; $24 \%$ of the remaining sample indicated signs of suicidality answering yes to questions such as: in the past month did you wish you were dead? Did you want to hurt yourself? Did you think of killing yourself? Did you think of a way to kill yourself? Of concern, 17 participants (5\%) reported attempting suicide in the past month.

(insert table 2 here)

Table 2 indicates significant variables related to depression, anxiety and PTSD. Days hungry was significantly correlated to all mental health problems. Results show high rates of comorbidity amongst depression, anxiety and PTSD. Females scored significantly higher for depression $(p<.001)$, anxiety $(p<.01)$, and PTSD $(p<.001)$ than males. Those reporting suicidality also reported significantly higher on all three mental health scales suggesting that suicidal individuals are more likely to present with higher levels of depression ( $p<.001)$, anxiety $(p<.001)$ and PTSD $(p<.001)$. Experiencing peer violence inside and outside of school, having been inappropriately touched, being hit, and not feeling safe at home all resulted significantly higher depression, anxiety, and PTSD. Knowing one's status was protective in terms of mental health with lower scores for depression $(p<.001)$, anxiety $(p<.001)$ and PTSD $(p<.05)$. Participants who reported being able to control their future and have dreams for their future where significantly less symptomatic compared to those who did not report this.

(insert table 3 here)

In an attempt to understand the symptomatic group within the larger sample, analysis was conducted comparing the symptomatic to the non-symptomatic group. Results are highlighted in table 3 on a range of significant variables. Experiencing hunger $(p<.001)$ and peer violence $(p<.001)$ were significantly related to being symptomatic. In addition, a significantly higher number of those in the symptomatic group (63\%) than those in the non-symptomatic group (47\%) experienced peer victimization both in and outside of school $(p<.05)$. This sample had high levels of exposure to violence with $16 \%$ reportedly seeing someone shot and $28 \%$ reportedly seeing someone stabbed in the community. 
Those in the symptomatic group were significantly more likely to report having been sick in the past year as opposed to the non-symptomatic group ( $46 \%$ vs $33 \%$ respectively, $\mathrm{p}=.02$ ). In addition, being treated badly as a result of someone being sick in the home was reported by a significantly higher portion of those in the symptomatic group than those in the non-symptomatic group (17\% vs $9 \%$ respectively, $p=.04)$.

(insert table 4 here)

Table 4 indicated the unadjusted relative risk of being symptomatic for 4 categories: depression, anxiety, PTSD or any of the 3 diagnoses. Being inappropriately touched increased the risk for being symptomatic for depression ( $R R=2.22, p=.01,95 \% \mathrm{Cl})$ and PTSD (RR=3.08, $p=.02,95 \% \mathrm{Cl}$ ), but not for anxiety. Experiencing forced sex led to a significantly higher relative risk of experiencing depression ( $R R=3.55, p=.02,95 \% \mathrm{Cl})$, anxiety $(R R=3.01, p=.01,95 \% \mathrm{Cl})$, and PTSD $(R R=2.38, p=.04,95 \% \mathrm{Cl})$. Experiencing peer violence at school increased the risk of experiencing PTSD ( $R R=2.56, p=.21,95 \%$ $\mathrm{Cl}$ ) but not depression or anxiety. However, experiencing peer violence outside of school increased the risk of experiencing depression ( $R R=2.16, p=.01,95 \% \mathrm{Cl})$ and PTSD ( $R R=2.80, p=.07,95 \% \mathrm{Cl}$ ) but not anxiety. There was a quantitative difference in the experience of violence in and out of school.

Those that did not feel safe at home showed a significantly higher risk of all three mental health disorders - depression $R R=5.17, p=.00$; anxiety $R R=2.92, p=.00$; and PTSD RR=3.94, $p=.02$ all $95 \% \mathrm{Cl}$. This was similar across all disorders (depression $R R=2.31, p=.00$; anxiety $R R=2.02, p=.00$; PTSD $R R=3.66, p=.01$ all $95 \% \mathrm{Cl}$ ) for those who reported that there was no safe place in the community for adolescents.

\section{Discussion}

This study described the mental health (depression, anxiety, PTSD) of HIV positive adolescents accessing care in Johannesburg, finding approximately a third $(27 \%)$ of these participants were symptomatic for any of these mental health disorders. In South Africa, the adjusted prevalence of mental disorders in adolescence has been estimated to be between 15-17\% (Patel et al, 2007; Kleintjes et al, 2006). Our findings indicate being HIV positive may be an important predictor of mental health problems in this population. This is a 'non-clinical' sample, i.e. they are not accessing healthcare for mental health, but rather for HIV care and treatment. Broadening the scope of intervention the health facility could be offering to curb the comorbid health problems of youth is recommended. Our study demonstrates the need for policy and public health practice to integrate HIV and mental health care for young people. 
Suicidality and suicidal ideation was high in this population ( $24 \%$ in the sample with $5 \%$ screened out at the start). This is not surprising as suicide is a major risk factor in adolescence both nationally and internationally. South African suicide rates range from 11.5 per 100000 to 25 per 100000 of the population; and on average $9.5 \%$ of non-natural deaths in young people are due to suicide (Schlebusch, 2012). Cluver et al (2015) have shown that suicide rates tend to increase amoung South African adolescents, as their exposure to adverse childhood events (e.g. parental death by AIDS or homicide, abuse, and exposure to community violence) accumulate. It is unclear what the attribution of orphan status and HIV diagnosis are to outcomes of suicidality, but these are arguably additional adverse childhood events that further the risk of suicidality. Of concern is that most of the adolescents in this sample, had not been asked about suicide before. Screening in such a high risk group seems necessary and a missed opportunity in linking them to appropriate care.

Strengthening clinical skills in managing and referring suicide in the healthcare system would require improvement for suitable and ethical treatment.

Evidence suggests that violence exposure is also related to suicidal behavior (Sorsdahl et al, 2011) and the experience of violence, both directly and indirectly, at school, in the home and the community had significant implications for mental health in this sample. Exposure to violence was strongly related to PTSD, but also to anxiety and depression to a lesser degree. Peer victimization in and outside of school was strongly associated with poor mental health outcomes indicating the need to address violence not only at community but also at school level and especially amongst adolescent peers. There was evidence to suggest the need for increased stigma reduction at the adolescent level related to ill health, particularly HIV. Poor relationships with peers, feelings of lack of security, and negative life events may increase the risk of mental disorders in adolescents (Cheng et al, 2014).

Unfortunately, although violence is an important risk factor for adverse mental health (Seedat et al, 2009), it is rarely screened for in young people who require protection. To date, most mental health research describing HIV positive patients tend to focus on depression and anxiety (Arseniou et al, 2013; Gutierrez et al, 2013) and this research highlights the need to manage PTSD equally. In addition, gender was strongly linked to poorer mental health outcomes in this sample, indicating a gendered screening approach is likely to identify those most at risk.

Although $78 \%$ of our sample reported having been disclosed to, only $50 \%$ knew how they became infected, and only $23 \%$ reported to disclosing their status to someone else. Adolescents need more reliable and comprehensive information regarding vertical transmission. Early and full disclosure (i.e. disclosure as a process over time) is strongly associated with improved adherence amongst ART-initiated adolescents 
(Cluver et al, 2015; Vas et al 2010). Research indicates that adolescents who have been told their HIV status and understand their diagnosis are significantly less anxious than those who haven't and those that know their status for longer report higher intentions to self-disclose to potential sex partners (Santamaria et al, 2011). Disclosure may be an essential tool in improving adolescent adherence and reducing mortality and onwards transmission. Our study also suggests that it is protective against mental health problems in adolescence; a compelling reason to support both families and healthcare providers to engage in disclosure with youth in their care (Santamaria et al, 2011; Kidia et al, 2014; Cluver et al, 2015). Empowered young patients who know their status and have improved agency as a result of it (Kidia, 2014), may more easily be able to think about their future and dream into it. These elements were found to be protective against mental health problems.

Almost $90 \%$ of this sample revealed they did not feel they belonged in the family they were being raised in. $90 \%$ reported that they did not get praise from those they live with, and $85 \%$ reported they did not get the same things as other children in the home. Given that these adolescents are being raised outside of their nuclear families, and live in environments characterized by high levels of migrancy, urban poverty, violence, and lack of family structure, these factors all exacerbate the burden of being infected. Emotional bonds to those taking care of them appear to be tenuous. In addition, adolescents who did not feel safe in their homes or communities showed higher mental health problems, indicating the need for increased social protection of this vulnerable population and recognition of this link to mental health problems.

\section{Implications for practice:}

Adolescence is a time for transformation of the adolescent-caregiver relationship; as adolescents establish relationships with peers and significant others outside the family, they expand their repertoire of coping skills and resources (Mutumba et al, 2016). Local research indicates that perceived support both from peers (Cluver et al, 2009) and from caring adults (Cheng et al, 2014) has significant positive effects on adolescent mental health. Therefore, healthcare personnel are well placed to have a positive and perceptibly supportive impact on young people who access them regularly. Although the physical environment presents many challenges and risks for adolescents living with HIV, the health system could be utilized to counter these effects. In addition, support groups at facility level hold promise in curbing mental health problems in HIV positive adolescents (Mupambireyi et al, 2014; Cheng et al, 2014). 
There are some critical indicators of mental health risk that could be incorporated into screening for adolescents at primary healthcare level. These include questions regarding if patients are hungry and whether they have been sick or hospitalized in the last year. There was a high probability that adolescents would be struggling with mental health problems if they did not feel they controlled their future or if they did not have a dream for the future. These questions could easily be asked in patient care and could lead to screening and referral for high risk patients who may feel their futures are foreclosed.

Interventions to meet the mental health challenges of HIV infected young people are gaining traction with varying success, in neighbouring African countries (Mavhu et al, 2013; Strasser \& Gibbons, 2014) and locally (Bhana et al, 2014). However, the variations in risk factors for this population underscores the need for a nuanced life course approach (Cluver et al, 2012), recognizing that young people are a population in transition. Dynamic and flexible interventions that seek to identify and address emerging threats and opportunities are required (Mutumba et al, 2016).

There are considerable challenges to implementing mental health interventions at public healthcare level that need to be thoroughly addressed for optimum impact. These include lack of skilled mental health professionals available to intervene and the need to utilize and upskill lay counselors to meet the demand ethically with targeted training and consistent expert supervision (Patel et al, 2011; Petersen et al, 2011; Breuer et al, 2011; Ventevogel, 2014; Mendenhall et al, 2014). Screening for mental health can lead to increased access to treatment but it is necessary to invest in screening instruments with high specificity, validity and reliability; that are short and can be administered easily in multiple languages (Kagee et al, 2013).

These findings should be interpreted within the limitations of the study. Participants were recruited from healthcare facilities in an urban setting so findings may not be generalizable to adolescents in other contexts. The study used self-report instruments susceptible to reporting bias and there may have been underreporting due to social desirability bias or stigma. However, tablet computers were utilized which have been shown to reduce reporting bias on sensitive questions (Gorbach et al., 2013; Jaspan et al., 2007; Toska, 2015). All psychological measures should be interpreted with caution in different cultures. There is a need for standardized scores and instruments for this context as the current instruments may not be capturing the full range of symptoms. There was no comparison group of HIV negative adolescents to assess the role of HIV in mental health problems. Despite these limitations, our findings have several important clinical and policy implications. They highlight young people accessing care and treatment are at risk for common mental health problems that are largely unrecognized and untreated and could be within the health system. 


\section{Conclusion}

Our findings underscore the need to improve efforts to reduce mental health problems in adolescents accessing care and treatment for HIV in public health settings. This sample was not deemed 'hard to reach' a term often associated with adolescent patients. Patients generally accessed care at least once every 3 months and were 'captive' in terms of the ability to influence their health outcomes. Not addressing the mental health concerns latent within the population speaks to gross missed opportunity. Not only in terms of impacting their current mental health and consequent benefits to their HIV care, but also in terms of curbing the poor adult outcomes likely to present later in more extreme forms as a result of untreated and unprevented early onset in adolescence (Das-Munshi et al, 2016; Patton et al, 2014). Promoting protective factors such as support, violence protection and access to mental health interventions at facility level could have positive effects on mitigating risk in a vulnerable population and addressing social factors that drive poor mental health. Policies that recognize this and support training for healthcare workers would strengthen the overall health of patients and maximize the value of the healthcare system in protecting and defending young people in South Africa.

\section{References}

Agwu, A. L., \& Fairlie, L. (2013). Antiretroviral treatment, management challenges and outcomes in perinatally HIV-infected adolescents. Journal of the International AIDS Society, 16(1).

Altman DG (1991). Practical statistics for medical research. London: Chapman and Hall.

Amaya-Jackson L. (1995) Child PTSD checklist. North Carolina: Duke Treatment Service.

Arseniou, S., Arvaniti, A., \& Samakouri, M. (2014). HIV infection and depression. Psychiatry and clinical neurosciences, 68(2), 96-109.

Becker, A. E., \& Kleinman, A. (2013). Mental health and the global agenda. New England Journal of Medicine, 369(1), 66-73.

Bernays, S., Rhodes, T., \& Barnett, T. (2007). Hope: a new way to look at the HIV epidemic. Aids, 21, S5-S11. 
Bhana, A., Mellins, C. A., Petersen, I., Alicea, S., Myeza, N., Holst, H., ... \& Leu, C. S. (2014). The VUKA family program: piloting a family-based psychosocial intervention to promote health and mental health among HIV infected early adolescents in South Africa. AIDS care, 26(1), 1-11.

Boyes, M. E., \& Cluver, L. D. (2013). Performance of the Revised Children's Manifest Anxiety Scale in a sample of children and adolescents from poor urban communities in Cape Town. European Journal of Psychological Assessment.

Boyes, M. E., Cluver, L. D., \& Gardner, F. (2012). Psychometric properties of the child PTSD checklist in a community sample of South African children and adolescents. PloS one, 7(10), e46905.

Breuer, E., Myer, L., Struthers, H., \& Joska, J. A. (2011). HIV/AIDS and mental health research in sub-Saharan Africa: a systematic review. African Journal of AIDS Research, 10(2), 101-122.

Children's Act, 2005

Cheng, Y., Li, X., Lou, C., Sonenstein, F. L., Kalamar, A., Jejeebhoy, S., ... \& Ojengbede, O. (2014). The association between social support and mental health among vulnerable adolescents in five cities: findings from the study of the well-being of adolescents in vulnerable environments. Journal of Adolescent Health, 55(6), S31S38.

Clacherty, G., \& Donald, D. (2007). Child participation in research: reflections on ethical challenges in the southern African context. African Journal of AIDS Research, 6(2), 147-156.

Cluver LD, Hodes RJ, Toska E, Kidia KK, Orkin FM, Sherr L, Meinck F. (2015) 'HIV is like a tsotsi. ARVs are your guns': associations between HIV-disclosure and adherence to antiretroviral treatment among adolescents in South Africa. AIDS, 1(29):S57-65.

Cluver, L., Orkin, M., Boyes, M. E., \& Sherr, L. (2015). Child and adolescent suicide attempts, suicidal behavior, and adverse childhood experiences in South Africa: a prospective study. Journal of Adolescent Health, 57(1), 52-59.

Cluver, L. D., Orkin, M., Gardner, F., \& Boyes, M. E. (2012). Persisting mental health problems among AIDS-orphaned children in South Africa. Journal of Child Psychology and Psychiatry, 53(4), 363-370.

Cluver, L., Fincham, D. S., \& Seedat, S. (2009). Posttraumatic stress in AIDS-orphaned children exposed to high levels of trauma: The protective role of perceived social support. Journal of Traumatic Stress, 22(2), 106-112. 
Cortina, M. A., Sodha, A., Fazel, M., \& Ramchandani, P. G. (2012). Prevalence of child mental health problems in sub-Saharan Africa: a systematic review. Archives of pediatrics \& adolescent medicine, 166(3), 276-281.

Das-Munshi, J., Lund, C., Mathews, C., Clark, C., Rothon, C. \& Stanfeld, S. (2016). Mental health inequalities in adolescents growing up in post-apartheid South Africa: Cross-sectional survey, SHaW Study. PloS ONE, 11(5), 1-16

Davies, M. A., \& Pinto, J. (2015). Targeting 90-90-90-don't leave children and adolescents behind. Journal of the International AIDS Society, 18(Suppl 6).

Department of Health, Medical Research Council, (2007). South Africa Demographic and Health Survey 2003. Pretoria: Department of Health.

Gadow, K. D., Angelidou, K., Chernoff, M., Williams, P. L., Heston, J., Hodge, J., \& Nachman, S. (2012). Longitudinal study of emerging mental health concerns in youth perinatally infected with HIV and peer comparisons. Journal of developmental and behavioral pediatrics: JDBP, 33(6), 456.

Gorbach, P.M., Mensch, B.S., Husnik, M., Coly, A., Mâsse, B., Makanani, B., Nkhoma, C., Chinula, L., Tembo, T., Mierzwa, S. and Reynolds, K., 2013. Effect of computerassisted interviewing on self-reported sexual behavior data in a microbicide clinical trial. AIDS and Behavior, 17(2): 790-800.

Gore, F. M., Bloem, P. J., Patton, G. C., Ferguson, J., Joseph, V., Coffey, C., ... \& Mathers, C. D. (2011). Global burden of disease in young people aged 10-24 years: a systematic analysis. The Lancet, 377(9783), 2093-2102.

Gutierrez, F., Garcia, L., Padilla, S., Alvarez, D., Moreno, S., Navarro, G., ... \& Masiá, M. (2014). Risk of clinically significant depression in HIV-infected patients: effect of antiretroviral drugs. HIV medicine, 15(4), 213-223.

Hudelson, C., \& Cluver, L. (2015). Factors associated with adherence to antiretroviral therapy among adolescents living with HIV/AIDS in low-and middle-income countries: a systematic review. AIDS care, 27(7), 805-816.

Jaspan, H.B., Flisher, A.J., Myer, L., Mathews, C., Seebregts, C., Berwick, J.R., Wood, R. \& Bekker, L-G. (2007). Brief report: Methods for collecting sexual behavior information from South African adolescents - a comparison of paper versus personal digital assistant questionnaires. Journal of Adolescence, 30: 353-359 
Kagee, A., Tsai, A. C., Lund, C., \& Tomlinson, M. (2012). Screening for common mental disorders in low resource settings: reasons for caution and a way forward.

International health, 5(1), 11-14.

Kim, S. H., Gerver, S. M., Fidler, S., \& Ward, H. (2014). Adherence to antiretroviral therapy in adolescents living with HIV: systematic review and meta-analysis. Aids, 28(13), 1945-1956.

Kidia, K. K., Mupambireyi, Z., Cluver, L., Ndhlovu, C. E., Borok, M., \& Ferrand, R. A. (2014). HIV status disclosure to perinatally-infected adolescents in Zimbabwe: a qualitative study of adolescent and healthcare worker perspectives. PloS one, 9(1), e87322.

Kieling, C., Baker-Henningham, H., Belfer, M., Conti, G., Ertem, I., Omigbodun, O., ... \& Rahman, A. (2011). Child and adolescent mental health worldwide: evidence for action. The Lancet, 378(9801), 1515-1525.

Kleintjes, S., Flisher, A., Fick, M, Railon, A., Lund, C., Molteno, C. et al (2012). The prevalence of mental disorders among children, adolescents and adults in the Western Cape, South Africa. South African Psychiatry Review, 9(3), 157-160

Kovacs, M. (1992). Children's depression inventory. North Tonawanda, NY: MultiHealth System.

Labadarios, D., Maunder, E., Steyn, N.,etal.(2003). National food consumption survey in children aged 1-9 years, South Africa Forum Nutrition 56:106e9.

Lecrubier, Y., Sheehan, D. V., Weiller, E., Amorim, P., Bonora, I., Sheehan, K. H., ... \& Dunbar, G. C. (1997). The Mini International Neuropsychiatric Interview (MINI). A short diagnostic structured interview: reliability and validity according to the CIDI. European psychiatry, 12(5), 224-231.

Lowenthal, E.D., Bakeera-Kitaka, S., Marukutira, T., Chapman, J., Goldrath, K. \& Ferrand, R.A. (2014). Perinatally acquired HIV infection in adolescents from subSaharan Africa: a review of emerging challenges. Lancet Infectious Disease, 14(7), 627-639

Mavhu, W., Berwick, J., Chirawu, P., Makamba, M., Copas, A., Dirawo, J., ... \& Mungofa, S. (2013). Enhancing psychosocial support for HIV positive adolescents in Harare, Zimbabwe. PLoS One, 8(7), e70254. 
Mellins, C.A. \& Malee, K.M. (2013). Understanding the mental health of youth living with perinatal HIV infection: lessons learned and current challenges. Journal of the International AIDS Society, 16, 1-19

Mellins, C. A., Tassiopoulos, K., Malee, K., Moscicki, A. B., Patton, D., Smith, R., ... \& Seage III, for the Pediatric HIV-AIDS Cohort Study, G. R. (2011). Behavioral health risks in perinatally HIV-exposed youth: co-occurrence of sexual and drug use behavior, mental health problems, and nonadherence to antiretroviral treatment. AIDS patient care and STDs, 25(7), 413-422.

Mendenhall, E., De Silva, M. J., Hanlon, C., Petersen, I., Shidhaye, R., Jordans, M., ... \& Tomlinson, M. (2014). Acceptability and feasibility of using non-specialist health workers to deliver mental health care: Stakeholder perceptions from the PRIME district sites in Ethiopia, India, Nepal, South Africa, and Uganda. Social science \& medicine, 118, 33-42.

Mofenson, L. M., \& Cotton, M. F. (2013). The challenges of success: adolescents with perinatal HIV infection. Journal of the International AIDS Society, 16(1).

Mupambireyi, Z., Bernays, S., Bwakura-Dangarembizi, M. \& Cowan, F.M. (2014). “I don't feel shy because I will be among others who are just like me...": The role of support groups for children perinatally infected with HIV in Zimbabwe. Children and Youth Services Review, 45,106-113

Mutumba, M., Bauermeister, J. A., Musiime, V., Byaruhanga, J., Francis, K., Snow, R. C., \& Tsai, A. C. (2015). Psychosocial challenges and strategies for coping with HIV among adolescents in Uganda: a qualitative study. AIDS patient care and STDs, 29(2), 86-94.

Mutumba, M., Bauermeister, J. A., Elkington, K. S., Bucek, A., Dolezal, C., Leu, C. S., \& Mellins, C. A. (2016). A Prospective Longitudinal Study of Mental Health Symptoms Among Perinatally HIV-Infected and HIV-Exposed but Uninfected Urban Youths. Journal of Adolescent Health, 58(4), 460-466.

Mynard, H. and Joseph, S. (2000). Development of the Multidimensional PeerVictimization Scale. Aggressive Behavior, 26(169-178).

Nel, A., \& Kagee, A. (2011). Common mental health problems and antiretroviral therapy adherence. AIDS care, 23(11), 1360-1365.

Ordóñez, A. E., \& Collins, P. Y. (2015). Advancing Research to Action in Global Child Mental Health. Child and adolescent psychiatric clinics of North America, 24(4), 679697. 
Patel, V., Chowdhary, N., Rahman, A., \& Verdeli, H. (2011). Improving access to psychological treatments: lessons from developing countries. Behaviour research and therapy, 49(9), 523-528.

Patel, V., Flisher, A. J., Nikapota, A., \& Malhotra, S. (2008). Promoting child and adolescent mental health in low and middle-income countries. Journal of Child Psychology and Psychiatry, 49(3), 313-334.

Patel, V., Flisher, A. J., Hetrick, S., \& McGorry, P. (2007). Mental health of young people: a global public-health challenge. The Lancet, 369(9569), 1302-1313.

Patel, V., Araya, R., Chatterjee, S., Chisholm, D., Cohen, A., De Silva, M., ... \& van Ommeren, M. (2007). Treatment and prevention of mental disorders in low-income and middle-income countries. The Lancet, 370(9591), 991-1005.

Patton, G. C., Coffey, C., Romaniuk, H., Mackinnon, A., Carlin, J. B., Degenhardt, L., ... \& Moran, P. (2014). The prognosis of common mental disorders in adolescents: a 14year prospective cohort study. The Lancet, 383(9926), 1404-1411.

Petersen, I., Ssebunnya, J., Bhana, A., \& Baillie, K. (2011). Lessons from case studies of integrating mental health into primary health care in South Africa and Uganda.

International Journal of Mental Health Systems, 5(8), 1-12

Petersen, I., Bhana, A., Myeza, N., Alicea, S., John, S., Holst, H., ... \& Mellins, C. (2010). Psychosocial challenges and protective influences for socio-emotional coping of HIV+ adolescents in South Africa: a qualitative investigation. AIDS care, 22(8), 970-978.

Pettifor A, Rees H, Kleinschmidt I, et al. (2003). Young people's sexual health in South Africa: HIV prevalence and sexual behaviors from a nationally representative household survey. AIDS, 19:1525e34.

Reynolds, C. R., \& Paget, K. D. (1983). National normative and reliability data for the revised Children's Manifest Anxiety Scale. School Psychology Review.

Richters, J. \& Martinez, P. (1993). The NIMH community violence project: Children as victims of and witnesses to violence. Psychiatry 56:7e21.

Santamaria, E. K., Dolezal, C., Marhefka, S. L., Hoffman, S., Ahmed, Y., Elkington, K., \& Mellins, C. A. (2011). Psychosocial implications of HIV serostatus disclosure to youth with perinatally acquired HIV. AIDS patient care and STDs, 25(4), 257-264.

SAPS Strategic Management (2005). Annual report of the South African Police Service 2004/2005. Johannesburg. 
Schlebusch, L. (2012). Suicide prevention: A proposed national strategy for South Africa. African Journal of Psychiatry, 15:436-440

Seedat, M., Van Niekerk, A., Jewkes, R., Suffla, S., \& Ratele, K. (2009). Violence and injuries in South Africa: prioritising an agenda for prevention. The Lancet, 374(9694), 1011-1022.

Sheehan, D., Shytle, D., \& Milo, K. (2004). MINI-KID: Mini International Neuropsychiatric Interview for Children and Adolescents. English Version, 4.

Sherr, L., Cluver, L. D., Betancourt, T. S., Kellerman, S. E., Richter, L. M., \& Desmond, C. (2014). Evidence of impact: health, psychological and social effects of adult HIV on children. Aids, 28, S251-S259.

Simbayi, L., Shisana, O., Rehle, T., Onoya, D., Jooste, S., Zungu, N., \& Zuma, K. (2014). South African national HIV prevalence, incidence and behaviour survey, 2012.

Pretoria: Human Sciences Research Council.

Skeen, S., Macedo, A., Tomlinson, M., Hensels, I. S., \& Sherr, L. (2016). Exposure to violence and psychological well-being over time in children affected by HIV/AIDS in South Africa and Malawi. AIDS Care, 28(sup1), 16-25.

Snider, L. \& Dawes, A. (2006). Psychosocial vulnerability and resilience measures for national-level monitoring of orphans and other vulnerable children:

Recommendations for revision of the UNICEF psychological indicator. Cape Town: UNICEF

Sorsdahl, K., Stein, D. J., Williams, D. R., \& Nock, M. K. (2011). Associations between traumatic events and suicidal behaviour in South Africa. The Journal of nervous and mental disease, 199(12), 928.

Stein, A., Desmond, C., Garbarino, J., Van IJzendoorn, M. H., Barbarin, O., Black, M. M., ... \& Bakermans-Kranenburg, M. J. (2014). Predicting long-term outcomes for children affected by HIV and AIDS: perspectives from the scientific study of children's development. Aids, 28, S261-S268.

Strasser, S., \& Gibbons, S. (2014). The development of HIV-related mental health and psychosocial services for children and adolescents in Zambia: the case for learning by doing. Children and Youth Services Review, 45, 150-157. 
Toska, E., Cluver, L. D., Hodes, R., \& Kidia, K. K. (2015). Sex and secrecy: How HIVstatus disclosure affects safe sex among HIV-positive adolescents. AIDS care, 27(sup1), 47-58.

UNAIDS (2014). The gap report. Joint United Nations Program on HIV. AIDS. Geneva: Joint United Nations Programme on HIV/AIDS.

UNAIDS (2014). 90-90-90 An ambitious treatment target to help end the AIDS epidemic. Geneva, Switzerland: UNAIDS

UNICEF (2013). Towards and AIDS-free generation: Sixth stocktaking report. Geneva Ventevogel, P. (2014). Integration of mental health into primary healthcare in lowincome countries: Avoiding medicalization. International Review of Psychiatry, 26(6), 669-679.

Verma, K. (2013). Base of a research: good clinical practice in clinical trials. Journal of Clinical Trials, 3(1), 100-128.

WHO (2013). HIV and adolescents: Guidance for HIV testing and counselling and care for adolescents living with HIV: recommendations for a public health approach and considerations for policy-makers and managers. Geneva 
Table 1.

Hypothesized risk variables

\begin{tabular}{|c|c|c|c|}
\hline Variable & Measurement & Description of assessment & Reference \\
\hline Poverty & $\begin{array}{l}\text { South African National Food } \\
\text { Consumption Survey }\end{array}$ & $\begin{array}{l}\text { - } \text { past-week hunger at the child level } \\
\text { - } \quad \text { past-week insufficient food at the household level } \\
\text { - lack of any employment in the household }\end{array}$ & Labadarios et al., 2003 \\
\hline Child abuse & $\begin{array}{l}\text { UNICEF scales for sub-Saharan } \\
\text { Africa }\end{array}$ & $\begin{array}{l}\text { - physical abuse was described as beating with an object or } \\
\text { - deliberate harm } \\
\text { - } \text { emotional abuse was exposure to verbal abuse } \\
\text { - exposure to domestic conflict was verbal and physical } \\
\text { violence between adults in the household and whether } \\
\text { the adolescent felt safe at home }\end{array}$ & Snider \& Dawes, 2006 \\
\hline $\begin{array}{l}\text { Community } \\
\text { violence }\end{array}$ & $\begin{array}{l}\text { Child Exposure to Community } \\
\text { Violence Checklist }\end{array}$ & $\begin{array}{l}\text { - adapted to reflect most common community traumas for } \\
\text { children in South Africa, as identified by national police } \\
\text { statistics (SAPS 2005): assault, robbery and witnessing of } \\
\text { stabbings and shootings }\end{array}$ & $\begin{array}{l}\text { Richters \& Martinez, } \\
1993\end{array}$ \\
\hline Bullying & Peer Victimization Scale & $\begin{array}{l}\text { - items include: being called names, being hit or } \\
\text { threatened and having possessions broken or stolen }\end{array}$ & Mynard \& Joseph, 2000 \\
\hline $\begin{array}{l}\text { Sexual health } \\
\text { risk }\end{array}$ & $\begin{array}{l}\text { National Survey of HIV and Risk } \\
\text { Behaviour amongst Young South } \\
\text { Africans and the South African } \\
\text { Demographic and Health Survey }\end{array}$ & - checklist of items & $\begin{array}{l}\text { Pettifor et al., } 2003 \\
\text { Department of Health } \\
\text { \& Medical Research } \\
\text { Council, } 2007\end{array}$ \\
\hline Future outlook & & $\begin{array}{l}\text { - do you have a dream for yourself and your future? } \\
\text { - do you feel you can control your future? }\end{array}$ & \\
\hline
\end{tabular}


Table 2

Significant variables in relation to Depression, Anxiety, and PTSD

\begin{tabular}{|c|c|c|c|c|c|c|}
\hline \multirow{2}{*}{$\begin{array}{l}\text { Variable } \\
\text { Pearson's }\end{array}$} & \multicolumn{2}{|c|}{ Depression } & \multicolumn{2}{|c|}{ Anxiety } & \multicolumn{2}{|l|}{ PTSD } \\
\hline & Correlation & $\mathrm{p}$ & Correlation & $\mathrm{p}$ & Correlation & $\mathrm{p}$ \\
\hline Grade & ns & ns & ns & ns & 0,11 & 0,05 \\
\hline Age & ns & ns & ns & ns & 0,11 & 0,05 \\
\hline Days Hungry & 0,35 & 0,00 & 0,26 & 0 & 0,18 & 0,00 \\
\hline $\begin{array}{l}\text { Highest } \\
\text { Grade }\end{array}$ & ns & ns & ns & ns & 0,13 & 0,02 \\
\hline $\begin{array}{l}\text { Depression } \\
\text { Score }\end{array}$ & - & - & 0,61 & 0 & 0,52 & 0,00 \\
\hline Anxiety Score & 0,61 & 0,00 & - & - & 0,54 & 0,00 \\
\hline $\begin{array}{l}\text { Peer Violence } \\
\text { Score }\end{array}$ & 0,32 & 0,00 & 0,39 & 0 & 0,38 & 0,00 \\
\hline $\begin{array}{l}\text { Number of } \\
\text { losses }\end{array}$ & ns & ns & ns & ns & 0,12 & 0,03 \\
\hline PTSD Score & 0,52 & 0,00 & 0,54 & 0 & - & - \\
\hline T-tests & Mean & $\mathrm{p}$ & Mean & $p$ & Mean & $\mathrm{p}$ \\
\hline $\begin{array}{c}\text { Gender } \\
\mathbf{f} \\
\mathbf{m}\end{array}$ & $\begin{array}{l}3,31 \\
2,39\end{array}$ & 0,00 & $\begin{array}{l}4,76 \\
3,86\end{array}$ & 0,01 & $\begin{array}{l}19,45 \\
14,36\end{array}$ & 0,00 \\
\hline $\begin{array}{l}\text { Suicidality } \\
\text { yes } \\
\text { no }\end{array}$ & $\begin{array}{l}4,73 \\
2,27\end{array}$ & 0,00 & $\begin{array}{l}6,24 \\
3,77\end{array}$ & 0,00 & $\begin{array}{l}23,23 \\
15,25\end{array}$ & 0,00 \\
\hline $\begin{array}{l}\text { Peer Violence } \\
\text { Inside and } \\
\text { Outside of } \\
\text { School } \\
\quad \text { yes } \\
\quad \text { no }\end{array}$ & $\begin{array}{l}3,20 \\
2,38\end{array}$ & 0,01 & $\begin{array}{l}4,74 \\
3,97\end{array}$ & 0,02 & $\begin{array}{l}20,35 \\
14,58\end{array}$ & 0,00 \\
\hline $\begin{array}{l}\text { Experienced } \\
\text { Violence - } \\
\text { Inappropriate } \\
\text { Touch } \\
\quad \text { yes } \\
\quad \text { no }\end{array}$ & $\begin{array}{l}3,70 \\
2,53\end{array}$ & 0,01 & $\begin{array}{l}5,51 \\
4,05\end{array}$ & 0,00 & $\begin{array}{l}22,58 \\
15,90\end{array}$ & 0,00 \\
\hline
\end{tabular}




\begin{tabular}{|c|c|c|c|c|c|c|}
\hline $\begin{array}{l}\text { Experienced } \\
\text { Violence - } \\
\text { Been Hit } \\
\text { yes } \\
\text { no }\end{array}$ & $\begin{array}{l}3,63 \\
2,49\end{array}$ & 0,00 & $\begin{array}{l}5,52 \\
3,99\end{array}$ & 0,00 & $\begin{array}{l}21,98 \\
15,77\end{array}$ & 0,00 \\
\hline $\begin{array}{l}\text { Experienced } \\
\text { Violence - } \\
\text { Feel Safe at } \\
\text { Home } \\
\quad \text { yes } \\
\text { no }\end{array}$ & $\begin{array}{l}2,54 \\
5,67\end{array}$ & 0,00 & $\begin{array}{l}4,13 \\
6,94\end{array}$ & 0,00 & $\begin{array}{l}16,29 \\
28,94\end{array}$ & 0,00 \\
\hline $\begin{array}{l}\text { Know their } \\
\text { Status } \\
\text { yes } \\
\text { no }\end{array}$ & $\begin{array}{l}2,61 \\
4,41\end{array}$ & 0,00 & $\begin{array}{l}4,16 \\
6,09\end{array}$ & 0,00 & $\begin{array}{l}16,59 \\
22,50\end{array}$ & 0,02 \\
\hline $\begin{array}{l}\text { Control } \\
\text { Future } \\
\text { yes } \\
\text { no }\end{array}$ & $\begin{array}{l}2,53 \\
5,15\end{array}$ & 0,00 & $\begin{array}{l}4,04 \\
7,15\end{array}$ & 0,00 & $\begin{array}{l}16,35 \\
29,08\end{array}$ & 0,00 \\
\hline $\begin{array}{l}\text { Have Dream } \\
\text { yes } \\
\text { no }\end{array}$ & $\begin{array}{l}2,58 \\
6,00\end{array}$ & 0,00 & $\begin{array}{l}4,19 \\
6,46\end{array}$ & 0,01 & $\begin{array}{l}16,37 \\
30,77\end{array}$ & 0,00 \\
\hline
\end{tabular}

Table 3

Significant results for symptomatic vs. non-symptomatic groups

\begin{tabular}{|l|c|c|c|}
\hline & $\begin{array}{r}\text { Symptomatic } \\
\text { for } \\
\text { Vepression, } \\
\text { Variable }\end{array}$ & $\begin{array}{r}\text { Symptomatic } \\
\text { Anxiety, or } \\
\text { PTSD }\end{array}$ & $\begin{array}{r}\text { for } \\
\text { Depression, } \\
\text { Anxiety, or } \\
\text { PTSD }\end{array}$ \\
\hline value \\
\hline T-test & Mean & Mean & p \\
\hline Days Hungry & 0,48 & 0,18 & 0,00 \\
\hline $\begin{array}{l}\text { Peer } \\
\text { Violence } \\
\text { Score }\end{array}$ & 8,70 & 5,24 & 0,00 \\
\hline $\begin{array}{l}\text { Chi-Square } \\
\text { X }\end{array}$ & $\%$ and $n$ & $\%$ and $n$ & $p$ \\
\hline
\end{tabular}




\begin{tabular}{|c|c|c|c|}
\hline $\begin{array}{l}\text { Wish they } \\
\text { were dead }\end{array}$ & $20 \%(19)$ & $6 \%(13)$ & 0,00 \\
\hline $\begin{array}{l}\text { Want to hurt } \\
\text { self }\end{array}$ & $14 \%(13)$ & $6 \%(13)$ & 0,02 \\
\hline $\begin{array}{l}\text { Think about } \\
\text { killing self }\end{array}$ & $20 \%$ (19) & $10 \%(22)$ & 0,01 \\
\hline $\begin{array}{l}\text { Think about } \\
\text { a way of } \\
\text { killing self }\end{array}$ & $14 \%(13)$ & $5 \%(11)$ & 0,00 \\
\hline $\begin{array}{l}\text { Any } \\
\text { suicidality }\end{array}$ & $37 \%(34)$ & $16 \%(36)$ & 0,00 \\
\hline $\begin{array}{l}\text { Peer } \\
\text { Victimisation } \\
\text { Outside of } \\
\text { School }\end{array}$ & $63 \%(59)$ & $47 \%(108)$ & 0,01 \\
\hline $\begin{array}{l}\text { Peer } \\
\text { Victimisation } \\
\text { inside and } \\
\text { outside of } \\
\text { school }\end{array}$ & $52 \%(48)$ & $38 \%(87)$ & 0,02 \\
\hline $\begin{array}{l}\text { Been sick } \\
\text { this year }\end{array}$ & $46 \%(43)$ & $33 \%(76)$ & 0,02 \\
\hline $\begin{array}{l}\text { Been hit or } \\
\text { attacked }\end{array}$ & $33 \%(31)$ & $14 \%(33)$ & 0,00 \\
\hline $\begin{array}{l}\text { Been treated } \\
\text { badly } \\
\text { because } \\
\text { someone in } \\
\text { family is sick }\end{array}$ & $17 \%(16)$ & $9 \%(21)$ & 0,04 \\
\hline $\begin{array}{l}\text { Have a safe } \\
\text { place for } \\
\text { adolescents } \\
\text { in the } \\
\text { community }\end{array}$ & $44 \%(41)$ & $70 \%(161)$ & 0,00 \\
\hline
\end{tabular}

Table 4

Relative risk of being symptomatic 


\begin{tabular}{|c|c|c|c|c|c|c|c|c|}
\hline \multirow[t]{2}{*}{ Variable } & \multicolumn{2}{|c|}{$\begin{array}{l}\text { Are this times } \\
\text { more likely to } \\
\text { become } \\
\text { symptomatic for } \\
\text { Depression }\end{array}$} & \multicolumn{2}{|c|}{$\begin{array}{l}\text { Are this times } \\
\text { more likely to } \\
\text { become } \\
\text { symptomatic for } \\
\text { Anxiety }\end{array}$} & \multicolumn{2}{|c|}{$\begin{array}{l}\text { Are this times } \\
\text { more likely to } \\
\text { become } \\
\text { symptomatic for } \\
\text { PTSD }\end{array}$} & \multicolumn{2}{|c|}{$\begin{array}{l}\text { Are this times } \\
\text { more likely to } \\
\text { become } \\
\text { symptomatic for } \\
\text { any }\end{array}$} \\
\hline & $\begin{array}{l}\text { Relative } \\
\text { Risk }\end{array}$ & $\mathrm{p}$ & $\begin{array}{l}\text { Relative } \\
\text { Risk }\end{array}$ & $p$ & $\begin{array}{l}\text { Relative } \\
\text { Risk }\end{array}$ & $\mathrm{p}$ & $\begin{array}{c}\text { Relative } \\
\text { Risk }\end{array}$ & $p$ \\
\hline $\begin{array}{l}\text { Been } \\
\text { inappropriately } \\
\text { touched }\end{array}$ & 2,22 & 0,01 & ns & ns & 3,08 & 0.0228 & ns & ns \\
\hline $\begin{array}{l}\text { Do not feel like } \\
\text { they control } \\
\text { their future }\end{array}$ & 2,55 & 0,04 & 2,75 & 0,00 & 8,11 & 0.0001 & 2,37 & 0,00 \\
\hline $\begin{array}{l}\text { Do not feel } \\
\text { safe at home }\end{array}$ & 5,17 & 0,00 & 2,92 & 0,00 & 3,94 & 0.0208 & 2,76 & 0,00 \\
\hline $\begin{array}{l}\text { Do not have a } \\
\text { dream }\end{array}$ & 4,62 & 0,00 & 2,25 & 0,00 & 7,92 & 0.0001 & 2,57 & 0,00 \\
\hline $\begin{array}{l}\text { Do not have a } \\
\text { safe place in } \\
\text { the community } \\
\text { for adolescents }\end{array}$ & 2,31 & 0,00 & 2,02 & 0,00 & 3,66 & 0.0138 & 2,10 & 0,00 \\
\hline $\begin{array}{l}\text { Experienced } \\
\text { forced sex }\end{array}$ & 3,55 & 0,02 & 3,01 & 0,01 & 2,38 & 0.4021 & ns & ns \\
\hline $\begin{array}{l}\text { Experienced } \\
\text { peer violence } \\
\text { at school }\end{array}$ & ns & ns & ns & ns & 2,56 & 0.2075 & ns & ns \\
\hline $\begin{array}{l}\text { Experienced } \\
\text { peer violence } \\
\text { outside of } \\
\text { school }\end{array}$ & 2,16 & 0,01 & ns & ns & 2,80 & 0.068 & ns & ns \\
\hline $\begin{array}{l}\text { Report any } \\
\text { form of } \\
\text { suicidality }\end{array}$ & 3,44 & 0,00 & 2,35 & 0,01 & 3,58 & 0.0081 & 2,09 & 0,00 \\
\hline
\end{tabular}




\begin{tabular}{|c|c|c|c|c|c|c|c|c|}
\hline $\begin{array}{l}\text { Think about a } \\
\text { way to kill } \\
\text { themselves }\end{array}$ & 3,54 & 0,00 & 2,23 & 0,00 & 4,18 & 0.0077 & 2,03 & 0,00 \\
\hline $\begin{array}{l}\text { Think about } \\
\text { killing } \\
\text { themselves }\end{array}$ & 3,22 & 0,00 & ns & ns & 5,39 & 0.0004 & ns & ns \\
\hline $\begin{array}{l}\text { Try to kill } \\
\text { themselves }\end{array}$ & 3,76 & 0,00 & 2,52 & 0,00 & 3,17 & 0.1013 & 2,37 & 0,00 \\
\hline $\begin{array}{l}\text { Want to hurt } \\
\text { themselves }\end{array}$ & 2,74 & 0,00 & ns & ns & 3,54 & 0.0199 & ns & ns \\
\hline $\begin{array}{l}\text { Wish they } \\
\text { were dead }\end{array}$ & ns & ns & 2,54 & 0,00 & 2,11 & 0.2222 & 2,34 & 0,00 \\
\hline
\end{tabular}

